\title{
Determining the Challenges Encountered by Chinese Expatriates in Pakistan
}

\author{
Muhammad Noman ${ }^{1}$, Muhammad Safdar Sial ${ }^{2}$, Talles Vianna Brugni ${ }^{3}{ }^{\mathbb{C}}$, Jinsoo Hwang ${ }^{4, *} \mathbb{C}$, \\ Muhammad Yaseen Bhutto ${ }^{5}$ and Thai Hong Thuy Khanh ${ }^{6, *}$ \\ 1 School of Journalism and mass communication, Wuhan University, Wuhan 430072, China; \\ noman_durrani@whu.edu.cn \\ 2 Department of Management Sciences, COMSATS University Islamabad (CUI), Islamabad 44000, Pakistan; \\ safdarsial@comsats.edu.pk \\ 3 Accounting Department, FUCAPE Business School, Av. Fernando Ferrari, 1358, Boa Vista, \\ Vitória-ES 29075-505, Brazil; tallesbrugni@fucape.br \\ 4 The College of Hospitality and Tourism Management, Sejong University, 98 Gunja-Dong, Gwanjin-Gu, \\ Seoul 143-747, Korea \\ 5 Economics and Management School, Wuhan University, Wuhan 430072, China; yaseen_bhutto@whu.edu.cn \\ 6 Faculty of Finance and Accounting, Nguyen Tat Thanh University, Ho Chi Minh City 700000, Vietnam \\ * Correspondence: jhwang@sejong.ac.kr (J.H.); thtkhanh@ntt.edu.vn (T.H.T.K.)
}

Received: 2 January 2020; Accepted: 10 February 2020; Published: 12 February 2020

check for updates

\begin{abstract}
The workforce of growing globalization has led to a large number of expatriate employees working overseas for short term employment. An expatriate assignment is strongly correlated with a variety of difficulties that affect expatriates' adjustment abroad. Therefore, the aim of this article is: (1) to determine the challenges encountered by Chinese expatriates in Pakistan and (2) to determine the role of cross-cultural training for a successful international assignment. The paper adopts a qualitative approach by conducting semi-structured interviews; the interviews were conducted with 22 males and eight females, forming a total of 30 Chinese employees with the average age of 34.5 years, working in different Chinese organizations in Pakistan in 2018. The findings of this study revealed that the most significant challenges faced by Chinese expatriates in Pakistan were cultural differences and language barriers in both work and non-work factors, whereas, those Chinese expatriates who were trained through formal and informal learning techniques could facilitate their cross-cultural adjustment.
\end{abstract}

Keywords: cross-cultural adjustment; cross-cultural training (CCT); challenges; Chinese expatriates; formal and informal learning

\section{Introduction}

Sustainability and culture have been widely discussed, but to date they have rarely been combined. The concepts of 'sustainability' and 'sustainable development' persist in policy and research despite the criticism and skepticism that they have been facing, as a result of uncertainties, since the concept of 'sustainability' was first introduced. "Culture" is also widely debated across scientific disciplines and policy areas, and is attracting attention as its own aspect of the sustainability debate [1,2]. This also raises awareness of the fact that the protection and promotion of cultural diversity is vital to universal human rights, fundamental freedoms and ensuring ecological and genetic diversity. This opinion is based on the view that sustainable development can only be achieved if there is consistency and reconciliation between cultural diversity and environmental responsibility and economic viability. The past few years have reflected the increasing investment by China in various countries around the world [3,4]. This has led to a large number of Chinese expatriates moving around the globe $[5,6]$. 
The 2013 Belt and Road Initiative is one of China's significant global investments [7]. This initiative focuses on territorial connectivity and economic development and covers a wide range of countries from China to South East Asia, East Africa, West Asia, Greece, Venice, and then Rotterdam [8]. Since the initiation of the Belt and Road Initiative, a big proportion of Chinese firms and expatriates have shifted to Pakistan [5], and adjusted to Pakistan's work and non- work spheres.

In the cross-cultural literature, expatriate adjustment has been a dominant research area [9-14]. According to Black, et al. [15], expatriates face many challenges linked to living and working abroad during their tasks. The resulting difficulties in adjusting to these settings resulted in a lively debate about how to improve effectiveness in the host country and decrease an expatriate assignment's failure. Black and Stephen suggested that expatriates are considered adjusted to the host culture if they experience comfort and psychological satisfaction and a lack of distress on three aspects of expatriate adjustment, i.e., general, interaction, and work adjustment [16].

In a foreign cultural climate, expatriates switch to working and living overseas [17], and as a result, expatriates are suffering from cultural shock, differences in working standards, loneliness, home-sickness, diverse healthcare systems, a different education system, a diverse culture and language, and food and other living expenses. Expatriates encounter difficulties linked to their work as well as social transitions; if these issues are unresolved, then the expatriates may get depressed, and their professional life will be affected, with a diverse impact on their overseas performance [18].

Cross-cultural adjustment is a method of adapting to the needs of foreign cultural environment which means altering views and belief systems according to the foreign culture. According to Neuliep James [19], because of diverse cultural values and unexpected conditions and principles, expatriates will become confused and anxious. As expatriates move to the host country and encounter the host culture, their beliefs, norms, and values are dependent on their home country's culture. Expatriates may encounter culture shock because the host culture and their own culture are completely diverse. This is a psychological process where expatriates experience uncertainty, depression, nervousness, homesickness and anger, and feel harassed [20].

Expatriates also encounter work pressure and insecurity in overseas tasks due to diverse cultural norms, language, and perceptions of acceptable actions [21]. Grundey [22] argues that, for a successful international assignment, cross-cultural training (hereafter CCT) efficiency is significant, as specific CCT may minimize the cultural shock and psychological stress, which often determines the expatriates' failure. The successful CCT may assist expatriates in becoming familiar with the host country's culture, laws, regulations, work culture, and other features, hence facilitating expatriates' cross-cultural adjustment while working abroad.

Our study contributes to two major aspects of the literature. Firstly, the study explores the challenges experienced by Chinese expatriates while adjusting to Pakistan's work and non-work environment. Secondly, the literature shows that the skill of adjusting to diverse cultures is one of the essential aspects of a foreign assignment. Thus, CCT performs a significant role. The primary objectives of CCT methods are to help understand the significance of culture to expatriate employees and to make them aware of cultural diversity, as well as explaining the beneficial role of CCT in the expatriates' adjustment and minimizing cultural shock [23].

The aim of this study is to explore the factors that affect Chinese expatriates' adjustment, and, particularly, to determine the challenges faced by Chinese expatriates during international assignment in Pakistan. Further, the study is interested in finding out how to mitigate challenges while on foreign assignments; for instance, the role of cross-cultural training in expatriates' adjustment.

\section{Literature Review}

\subsection{Expatriate Cross-Cultural Adjustment}

In the literature on cross-cultural adjustment, a differentiation was made between socio-cultural adjustment and psychological adjustment $[24,25]$. Although conceptually interconnected, socio-cultural 
adjustment is linked to the capacity to "fit in" or communicate successfully with representatives of the host country [26], whereas psychological adjustment relates to the psychological well-being or happiness of a person in their new social and cultural environment. The idea of psychological adjustment includes a problem-oriented interpretation of the transition method, based on attitudinal variables $[27,28]$.

The idea of becoming an expatriate seems attractive, but most people struggle to adjust to their new environment. Expatriates will be isolated in the host country if they have contact with a limited amount of host nationals, and this will be exacerbated if the host language is not spoken well. This will be carefully observed, because an expatriate who doesn't like his or her international task will start searching for work abroad. In contrast, numerous scholars have described the degree of psychological satisfaction of an individual with certain aspects of their new environment [29-31].

According to Black [32], adjustment can be defined in three dimensions: (1) the expatriate's degree of comfort with his or her working domain is referred to as work adjustment, (2) the expatriate's degree of comfort with his or her social interaction with host citizens is referred to as interaction adjustment, and (3) the expatriate's degree of comfort with the host country's cultural surrounding is referred to as general adjustment.

\subsection{Challenges in Cross-Cultural Adjustment}

The research literature is gradually realizing that overseas employment can be a stressful and exhausting activity and that psychological assistance in the foreign country will relieve the anxiety of expatriates and enhance their initial adjustment [33,34].

Expatriates working abroad will have adjustment issues in general as to how to interact with host nationals and the foreign working atmosphere. In the available literature focused on expatriates, it's also a struggle to work and live in diverse cultural settings, therefore it's not strange that the lack of cultural understanding and language skills, and the challenges of adjusting to the host culture, are significant factors leading to the failure of expatriates $[35,36]$. Therefore, it is essential for expatriates to know about the host culture, become conscious of cultural differences, and have expertise in cross-cultural interactions, so that they will be able to adapt to the foreign culture and conduct a productive international task.

Nevertheless, an increasing amount of studies have shown that expatriates are inefficient in host countries $[37,38]$ and outline the problems for expatriates when working in the diverse cultural environment $[5,11,39,40]$. To analyze the expatriates' cross-cultural adjustment, mainly focusing on "work factors" using powerful approaches [41,42], the importance of working dynamics was limited to understanding the consequences of task clarification for expatriates [11]. There was also a need to recognize "non-work" factors [12,43,44].

While several past studies have highlighted the different approaches used for both work and non-work spheres of expatriates [45,46]. Parhizgar [45] states that social networks of expatriates in abroad are particularly essential in both work and non-work domains, as these networks will assist the expats in learning about the country's rules, regulations, and culture in a more realistic way, and guides them with essential knowledge about the host culture standards, customs, and how to resolve any hurdles and difficulties which may impede their progress.

Several other scholars have mentioned in their studies that expats' positional discrepancies also perform an important role in work domains, for instance, top level management expats were usually engaged in organizational decision-making, and therefore, the clarification of position will not be as essential to them as middle and low-level management [47].

\subsection{Facilitating Expatriate Cross-Cultural Adjustment}

In the context of an expatriates' cross-cultural adjustment, the researchers have identified that CCT is the most effective method to help with expatriates' adjustment abroad [48,49]. CCT gives expatriates the opportunity to learn different things. It equips them with the knowledge needed 
to identify, understand and act on different cultural nuances, overcome any difficulties they might experience, develop meaningful and beneficial relationships with other people, and cope with any pressures and stressors they may experience [50]. CCT aims at educating a person of one culture to communicate successfully with a person of other cultures and help them to easily adapt to their new role $[51,52]$.

\subsection{Cross-Cultural Training (CCT)}

Expatriate CCT has been crucial. The scholars acknowledged that CCT performs a key role in expatriates' effective foreign adjustment [53]. In addition, CCT is often described as a method aimed at increasing the capacity of individuals to manage and function properly abroad [54]. Black and Mendenhall [55] stated that CCT has been introduced as a way to facilitate successful cross-cultural relationships. Training strengthens the cultural attitude of expatriates and allows them to realize their environment abroad [56]. Caligiuri, et al. [57] pointed out that CCT was intended to help employees feel confident living and working abroad and it will also strengthen their adjustment and improve their ability to recognize and understand different cultural backgrounds. Through the implementation of adequate planning, such as offering CCT to these expatriates prior to a foreign assignment most challenges will be minimized or avoided.

According to Deal [58], CCT will minimize the culture shock and the impacts and shocks that individuals feel subsequent to confronting a new culture. Due to CCT, expatriates encounter less cultural shock and adjust quickly in the host country as compared to those expatriates without CCT [23]. Mondy and Noe [59], suggested that different kinds of pre-departure and CCTs involving host country language, culture, living standards, and cultural norms will help expatriates to adjust easily in the host environment. CCT performs a key role in expatriate's successful foreign assignment. As a result, this training is aimed at advancing the expatriates' awareness of the host culture and making them familiar with cultural differences.

\subsection{Formal and Informal Learning}

The literature on cross-cultural training (CCT) suggested that expatriates will learn in two ways (i.e., formal learning and informal learning). CCT has been recognized as an essential method of promoting the learning and improvement of the skills that expats need to work effectively abroad $[60,61]$. Most of the past studies argue that pre-departure training is very effective, but this training can performed in foreign countries as well [62]. A short time period of pre-departure training will not entirely perpare expatriates for the difficulties they may encounter while on foreign assignment, and then training should begin after settling in the host country [62]. Sims and Schraeder [63] narrated that post-arrival training is extremely useful in minimizing culture shock and cross-cultural adjustment challenges in host country. As a result, these will contribute to facilitating the expatriates' basic needs, such as legal issues, children's education system, and other common guidelines on performing fundamental things in the host country [64].

Tissot, [65] describes "Formal learning" as the typical learning offered by a company or training agency. These firms provide training programs for expatriates before they take on an international task (in which they assume their responsibilities for a global project before heading to that country). Brewster and Pickard [66] reported in their study that about half of European companies provide their employees with formal cross-cultural training prior to departure on international assignments. Ghafoor and Khan [67] have conducted a study regarding Asian companies; they also offer training to their employees before sending them on foreign tasks.

Informal learning is regarded as a continuous mechanism, in which information, behavior, knowledge, and experience is learned. This can be deliberate or accidental, and the creation of strategies and innovations is promoted. We are living in a digital environment that provides us with unlimited resources for informal learning. Informal learning is sought from life and work experiences through working professionals and peers through internet use, guidance, and technical networks, 
etc. Furthermore, these informal training techniques are mostly organized by expatriates themselves, although sometimes the company offers such informal training to them [66]. Several approaches and resources are used for informal learning. Bear, et al. [68] argues that the majority of expatriates use internet technologies as a source of informal learning to acquire information about the host county and its culture, for example, YouTube, Google, Facebook, Whatsapp, Wechat.

Informal learning is also gained through everyday work and social activities. Sambrook [69] argues that informal learning occurs in the working environment through evaluation, practicing and so on, instead of through taking part in a formal training class while working. For instance, informal learning may take place through staff meetings, client relations, coaching, peer-to-peer conversations, and exploring new work [70,71].

\section{Methodology}

Past studies on expatriate adjustment focused on quantitative methods [9,43,72]. Although some have also used qualitative methods [40,73], according to Birkinshaw, et al. [74] and Yin [75], qualitative methodologies offer the ability to better understand adjustment strategies across cultures; therefore, "qualitative techniques" have been used in this research to comprehensively analyze the cycle of Chinese expatriates' adjustment.

In this study, we gathered data via semi-structured interviews from Chinese expatriates working in various Chinese firms in Pakistan in 2018. Selmer [14] argued that these qualitative techniques may help the scholar to resolve "language barriers" while collecting data and also help Chinese expatriates to comprehend the research question by answering their concerns. The study follows two specific approaches consisting of "narrative analysis" that were incorporated into the study model $[76,77]$, and this technique was used in order to make the interviewees confidently express their experiences in the interview [75].

\subsection{The Study Configurations}

As we mentioned previously, the focus of this study is Chinese expatriates who have worked in various Chinese firms in Pakistan. Most of these Chinese firms are situated in Islamabad (capital of Pakistan) owing to stringent security protocols [78,79]. These companies operate in various domains and the majority of these companies are operating in the energy, infrastructure, construction, manufacturing, engineering, petroleum, telecommunications, and IT fields.

In order to expand the sample, a "snowballing sampling technique" was used to access the respondents, because this technique is especially effective in qualitative research [80]. This included asking every participant whether someone they know would be helpful in this project and the author would also interview those participants [81]. This sampling approach has proved effective in past studies in this domain $[82,83]$.

\subsection{The Participants}

In order to make the collected data richer and more systematic and informative, three main selection criteria have been implemented, thereby leading to an in-depth analysis and interpretation of the subject explored in this research:

- The participants have at least one year of work experience in Pakistan;

- Participants must be working in Chinese firms in Pakistan;

- Participants have the ability to speak English, as the interviews were performed in English.

The study comprised 22 males and eight females. The participants' average age was 34.5 years old, whereas the average working tenure was 2.8 years in Pakistan. Table 1 offers information about the interviewees and the length of the interviews. 
Table 1. Participants Information.

\begin{tabular}{|c|c|c|c|c|c|}
\hline $\begin{array}{l}\text { Identity of } \\
\text { Participants }\end{array}$ & Working Sector & $\begin{array}{c}\text { Participants } \\
\text { Age }\end{array}$ & $\begin{array}{l}\text { Working } \\
\text { Experience } \\
\text { (Years) }\end{array}$ & $\begin{array}{l}\text { Interview } \\
\text { Length } \\
\text { (minutes) }\end{array}$ & $\begin{array}{c}\text { Transcribed } \\
\text { Words }\end{array}$ \\
\hline Participant 1 & Telecommunication & 29 & 1.5 & 30 & 1328 \\
\hline Participant 2 & Telecommunication & 30 & 3 & 15 & 718 \\
\hline Participant 3 & Telecommunication & 34 & 2 & 18 & 1173 \\
\hline Participant 4 & Telecommunication & 36 & 2 & 20 & 1132 \\
\hline Participant 5 & Telecommunication & 31 & 2.5 & 17 & 1257 \\
\hline Participant 6 & Telecommunication & 37 & 4 & 24 & 1406 \\
\hline Participant 7 & Telecommunication & 35 & 3 & 19 & 1224 \\
\hline Participant 8 & Telecommunication & 29 & 2 & 21 & 1146 \\
\hline Participant 9 & Telecommunication & 30 & 2 & 16 & 1009 \\
\hline Participant 10 & Telecommunication & 31 & 1 & 15 & 773 \\
\hline Participant F11 & Telecommunication & 33 & 3 & 18 & 896 \\
\hline Participant 12 & Telecommunication & 30 & 2 & 19 & 1097 \\
\hline Participant 13 & Telecommunication & 35 & 2.5 & 20 & 1152 \\
\hline Participant 14 & Manufacturing & 34 & 1.5 & 22 & 1473 \\
\hline Participant 15 & Manufacturing & 38 & 2 & 17 & 1991 \\
\hline Participant 16 & Manufacturing & 33 & 1 & 19 & 872 \\
\hline Participant 17 & Manufacturing & 45 & 10 & 23 & 865 \\
\hline Participant 18 & Manufacturing & 39 & 4 & 25 & 1320 \\
\hline Participant 19 & Manufacturing & 42 & 3 & 21 & 1102 \\
\hline Participant20 & Manufacturing & 37 & 4 & 17 & 801 \\
\hline Participant 21 & Manufacturing & 43 & 8 & 24 & 1029 \\
\hline Participant 22 & Manufacturing & 36 & 3 & 25 & 1352 \\
\hline Participant F23 & Telecommunication & 39 & 5 & 19 & 1190 \\
\hline Participant 24 & Telecommunication & 28 & 1.5 & 23 & 1274 \\
\hline Participant F25 & Telecommunication & 29 & 1 & 26 & 1018 \\
\hline Participant 26 & Telecommunication & 33 & 2.5 & 17 & 933 \\
\hline Participant 27 & Manufacturing & 40 & 2 & 19 & 1090 \\
\hline Participant 28 & Manufacturing & 37 & 3 & 20 & 1101 \\
\hline Participant F29 & Manufacturing & 32 & 1 & 19 & 802 \\
\hline Participant F30 & Telecommunication & 30 & 1 & 23 & 985 \\
\hline Total Values & & 1035 & 84 & 611 & 33,509 \\
\hline
\end{tabular}

\subsection{The Interview Phase}

To find the best possible responses to the research questions on Chinese expatriate's experiences, the primary focus of the interviews was determining the aspects that will impact Chinese expats' adaptation. The challenges they encounter during their stay in Pakistan both in work and non-work spheres were particularly focused on, as well as how cross-cultural training will help to minimize these challenges.

The findings in Phase 1 of the interviews show that, while staying in Pakistan, Chinese expats face various challenges linked to their work and non-work spheres. Therefore, the guidelines for the interview were improved. In Phase 2 interviews with Chinese expats in order to understand CCT's role in their cross-cultural adjustment, the discussions intended to get information regarding Chinese expat encounters. Questions were structured to provide a convenient atmosphere for respondents in answering and, therefore, to contribute to "solid explanations" instead of just surface descriptions [84]. For this reason, the semi-structured interview questions were related to two main criteria. The first part contains the questions related to their experiences of challenges regarding "work factors and non-work factors" (e.g., what kind of challenges/problems are faced). The second part contains the facilitation provided for these challenges (i.e., cross-cultural training).

As for cross-cultural adjustment, the questions centered on what the Chinese expatriates viewed as being most difficult while engaging in cross-cultural activities and how well they adapted, mentally and 
behaviorally, to work and life overseas [15]. The researchers also ask questions as to whether or not the firm offered cross-cultural training to them or whether they self-directed their cross-cultural adjustment.

\subsection{The Procedure of Data Collection}

The semi-structured technique was used for data collection. The interviews were conducted with 30 Chinese employees who are working in various Chinese firms in Pakistan. Further, these semi-structured interviews were conduct by a team of three members. Most interviews were performed in firms, while some were in various Islamabad restaurants. The interviews lasted for about 15-30 min.

Initially, to inform the participants about the project specifics, an email was generated and sent, whereas the remaining participants were informed by their Pakistani work peers. To conserve the privacy of respondents, the interviewers recorded all the interviews after collecting information. In order to maintain factual findings, the interviews have been transcribed precisely. In addition, the participants also endorsed an agreement to participate in the interview process in the research [46].

\subsection{The Procedure of Data Analysis}

In this study, we analyzed data by using "MAXQDA 18," taking a five-stage procedure into effect [75]. Qualitative data analysis will be illustrated in five steps, i.e., compiling, disassembling, reassembling, interpreting, and concluding [85]. In the first step, searching for concrete responses concerning the research involves compilation of the data in a workable manner. Compilation may involve transcribing; after that, a researcher will feasibly have access to the data. In different cases, where data have been transcribed through interviews or focus groups, then researchers would recommend transcription by themselves [86]. The second step contains disassembling data; it includes sorting and creating accurate categories. This will also include a coding process in which raw data is transformed into meaningful information by defining themes and ideas that are linked to one another [86].The third step involves reassembling the data, in which the meaning assigned for each code and category, are created with an emphasis on the theme creation [87]. The fourth step involves the investigator drawing analytical conclusions through data identified as codes and as themes [85]. In the final step, every study will begin with a logical research question and respond to this question; it could simply be that the query has moved slightly during the process of data analysis [88].

Before interviewing, the "Thematic analysis" coding framework was used through a literature review and then modified by a systematic review of transcripts and codes [89]. Finally, Figure 1 presents the final version of the hierarchical coding framework. This section analyzes the framework of hierarchical coding, in which the analysis in each sub-heading outlines the results in each main category, and Flick [84] "narrative arrays" shows the participant's quotations (1). To preserve respondents' privacy, a code that distinguishes male and female participants covers each quote. Thus, "Participant 1" represents participant number 1, and "Participant F" represents "female", as shown in Table 1.

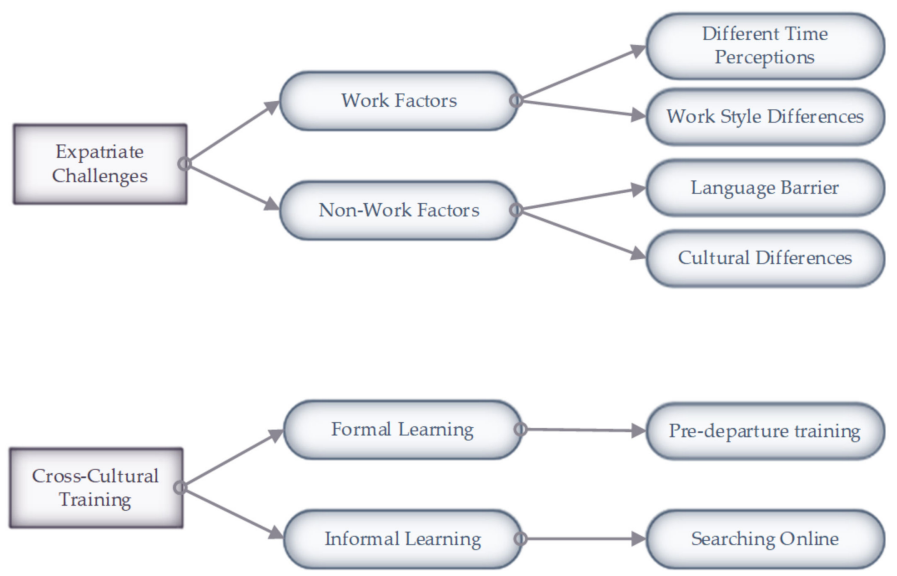

Figure 1. Final Coding structure. 


\section{Results}

The results of the study are discussed in two main areas. In the first part, the results have been presented as the challenges faced by Chinese expats in their adjustment in Pakistan, especially the challenges related to the "work factors and non-work factors" of Chinese expatriates. The second part explains the effectiveness of CCT in the cross-cultural adjustment of Chinese expatriates, specifically elaborating the way in which Chinese expats facilitate their adjustment (i.e., formal learning and informal learning).

\subsection{Cross-Cultural Adjustment Challenges in Pakistan}

During foreign assignments, expatriates encounter several difficulties and issues. To determine the obstacles of Chinese expats in Pakistan, researchers asked questions about two dimensions (i.e., work factors and non-work factors). The following segment illustrated the importance of these two factors. Some statements are shown in Table 2 in these two sections.

Table 2. Work factors.

\begin{tabular}{|c|c|}
\hline Themes & Quotations on Themes \\
\hline $\begin{array}{l}\text { Different time } \\
\text { perceptions }\end{array}$ & $\begin{array}{l}\text { "I think Chinese rules are different, we work according to the rules in China, we work } \\
\text { on time, and people are not working on time in Pakistan, and they don't know } \\
\text { about this" (Participant 1) } \\
\text { "Time management is a big challenge in Pakistan, they aren't on time, and another } \\
\text { issue is like when you call him to meet once you reach the location, then they told } \\
\text { you that we are not available. So why you didn't tell us early, this is also a } \\
\text { big concern" (Participant 28) } \\
\text { "When we call for meeting at 09:00 in Pakistan that means it will begin at 09:30, but in } \\
\text { China, if the meeting calls on 09:00, then it means 09:00" (Participant F25) } \\
\text { "Our Pakistani colleagues are on time, when we have daily meetings or monthly } \\
\text { meetings they are punctual. But sometimes when we have meetings with our clients } \\
\text { and they don't come on time but I think it's just because of their social life" } \\
\text { (Participant 6) }\end{array}$ \\
\hline Work style differences & $\begin{array}{l}\text { "There are many differences between Chinese and Pakistani workers. The main } \\
\text { reason for the different work styles due to cultural diversity" (Participant20) } \\
\text { "Chinese people are very hardworking and they goal oriented people, they always } \\
\text { complete their projects on time because they highly skilled, while on the other side } \\
\text { Pakistani workforce still don't have capacity, skills like Chinese people have. So the } \\
\text { work difference is just because of Pakistan workforce is less technology oriented as } \\
\text { compared to Chinese work force" (Participant14) } \\
\text { "Chinese people are more loyal to their work and assignments, they give more } \\
\text { priority to their work, while on the other side Pakistan people orientation is different, } \\
\text { they give more priority to other things such as families, gatherings, etc. So in my } \\
\text { point of view, these are work style differences as compared to Chinese people" } \\
\text { (Participant F30) } \\
\text { "It's a little hard to start a business here due to different way of work and cultural } \\
\text { diversity" (Participant F23) }\end{array}$ \\
\hline
\end{tabular}

\subsubsection{Work Factors}

Findings have identified two main hurdles faced by Chinese expatriates in their working environment in Pakistan (i.e., different time perceptions and work-style differences), and these are the most important challenges they faced while working in Pakistan. A large number of Chinese expatriates mentioned poor time-keeping in their interviews regarding their Pakistani colleagues. More than 18 participants said that people in Pakistan delay tasks and spend more time on social 
activities and interaction with people in the working domain, and therefore take more time to finish their assignments.

The second hurdle in the work factor is work-style differences. Working in a diverse environment and different cultures will create these hurdles because of differences in norms, ethics, and values in the working environment. A large majority of respondents highlighted concerns regarding work-style differences. This hurdle was commented on by more than 15 respondents; due to differences in both business and culture, they face these obstacles in Pakistan. Some exemplary quotations of Chinese expats are shown in Table 2.

\subsubsection{Non-Work Factors}

The results regarding Chinese expatriate's non-work factors highlighted two main hurdles during their stay in Pakistan (i.e., language barrier and cultural differences). These are the major concerns for Chinese expats in Pakistan. Language was mentioned as a barrier by more than 20 respondents in their interviews. Most of the Chinese expatriates said in their interviews that language issues are confronted when they interact with the local people of Pakistan. Many said in their responses that, in their organizations, they don't face language issues because almost everyone can speak English very well.

"Cultural differences" was the second hurdle in the adjustment of Chinese expats in Pakistan. A majority of respondents highlighted that culture is a very sensitive topic in every country, so they have to be very careful regarding Pakistan's culture. This obstacle was commented on by more than 18 respondents: in Pakistan, the majority of peoples are Muslims; many things are prohibited in Pakistan; and they must respect the local culture here. Some exemplary quotations of Chinese expats are shown in Table 3.

Table 3. Non-work factors.

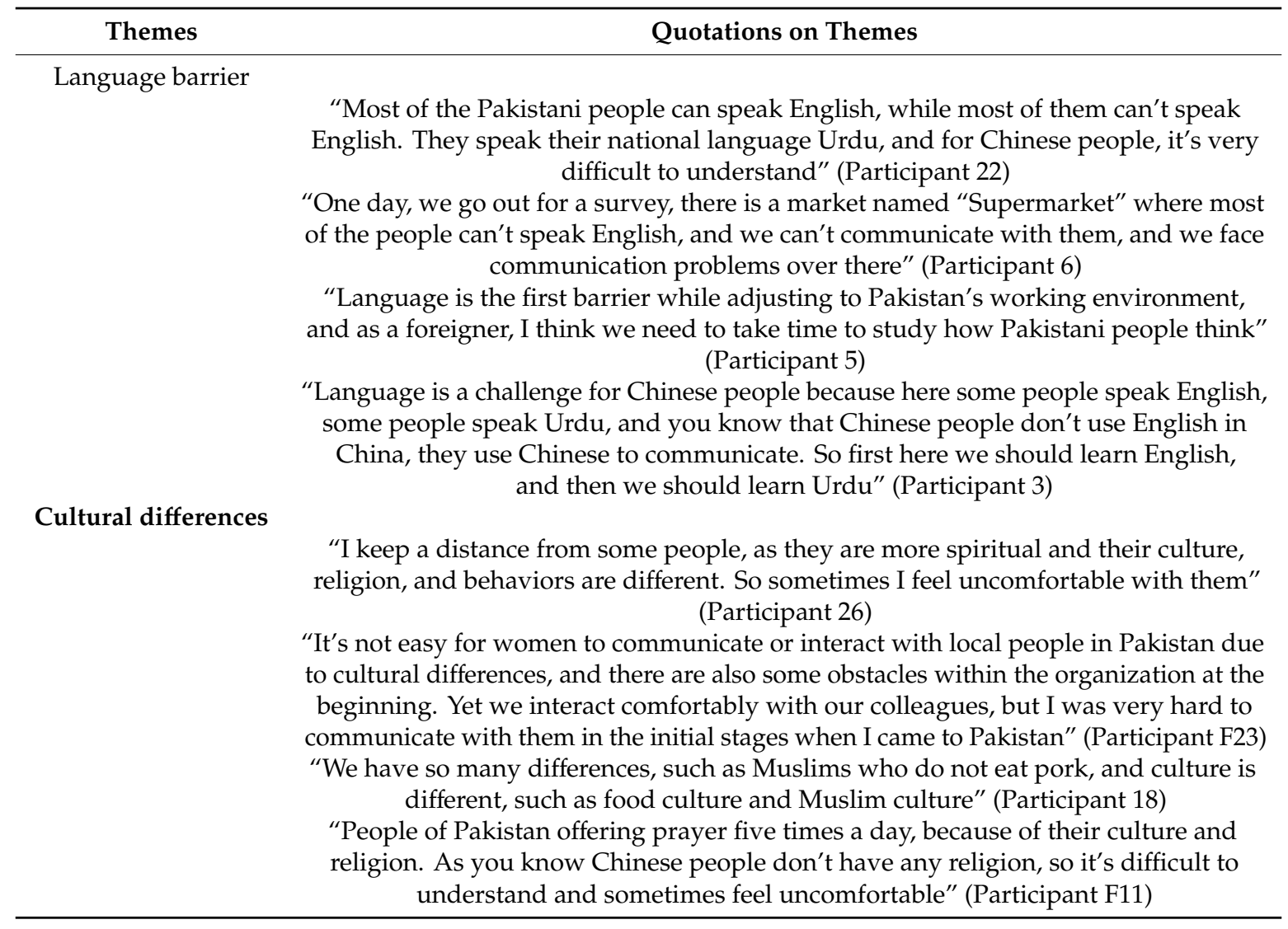




\subsection{Cross-Cultural Training Facilitates Cross-Cultural Adjustment}

The world is globalizing; individuals are living and working globally in diverse cultural environments from their homelands. Therefore, cross-cultural training intends to make expatriates feel confident in foreign assignments. In addition, this training will improve their adjustment and increase their knowledge and appreciation from different points of view. In the following section, findings have been presented in two areas (i.e., the formal learning and informal learning of Chinese expatriates).

\subsubsection{Formal Learning}

The findings on formal learning highlighted the techniques used for the success of expatriates in a host country (i.e., pre-departure training). Formal learning is mostly offered by the organization or a training institute. This aims to assist in successful adaption to working and living in a host country, and, most importantly, the host country's culture. The participants who conducted the pre-departure training commented that the training helps them adjust to Pakistan's working and living environment and also provided recommendations on how to act or behave in these environments. Some exemplary quotations of Chinese expats are shown in Table 4.

Table 4. Formal learning.

\begin{tabular}{|c|c|}
\hline Themes & Quotations on Themes \\
\hline Pre-departure training & $\begin{array}{l}\text { "We took one-week training in China because you know that there are different } \\
\text { cultures in China and Pakistan. More than 90\% of the peoples are Muslims in } \\
\text { Pakistan, so before that, we didn't meet with Muslim friends and Muslim families, } \\
\text { and we learned a lot about Muslim culture and Pakistan culture from them" } \\
\text { (Participant 3) } \\
\text { "When we go to any foreign country for employment, the company will offer } \\
\text { training to us, and the most important topic of training is to respect the culture, } \\
\text { even though you don't understand the culture, you have to respect the culture" } \\
\text { (Participant 5) } \\
\text { "I took the cross-cultural training, and it helps me a lot to understand the host } \\
\text { country culture and host country people" (Participant 27) } \\
\text { "Actually me and my Chinese fellow we came from a big company of China, } \\
\text { so before we came here there is a whole set of training you see how fluently I speak } \\
\text { English, this is just because of training, and the other thing you need to respect the } \\
\text { host culture and to respect everyone that's the most important thing the rest of this } \\
\text { you have to be here" (Participant 15) }\end{array}$ \\
\hline
\end{tabular}

\subsubsection{Informal Learning}

In a modern and globalized world, where technology enables people to gain knowledge in different ways, informal learning is gaining an extremely important role. Results regarding informal learning highlighted "searching online." A variety of techniques are used for informal learning, but, in the digital age, a well-known technique that most people use to become aware of what is happening in the world is internet technology. Most of the respondents commented that they use the internet as a tool to gather information about Pakistan and the people of Pakistan. Some exemplary quotations of Chinese expats are shown in Table 5. 
Table 5. Informal learning.

\begin{tabular}{l} 
Themes Quotations on Themes \\
\hline Searching online \\
"I can search online by myself and do not take orientation or cross-cultural training \\
before visiting Pakistan" (Participant 1) \\
"I didn't take any specific cross-cultural training. I only get information from the internet \\
regarding Pakistan. Pakistan is an Islamic country, the culture is different, so here we \\
must be careful because different people have different perceptions. Different \\
understanding telling me that we cannot shake hands with any woman, so we have to be \\
careful about this kind of difference" (Participant 6) \\
"No I didn't take any cross-cultural training, but the only way to get the information \\
about Pakistan is from internet, and I learned a lot about Pakistan from the Internet" \\
(Participant 16) \\
"No I just search on internet about Pakistan, and I also know the relationship of Pakistan \\
and China and their brotherhood relationships" (ParticipantF25)
\end{tabular}

\section{Discussion}

The main purpose of this study was to highlight the challenges faced by Chinese expatriates during their cross-cultural adjustment in Pakistan, and how to facilitate their cross-cultural adjustment.

In the expatriate literature, scholars have illustrated that expatriates in the host countries face different sorts of issues in their adjustment $[5,9,39,40]$. The study elaborated on two-dimensional problems (i.e., work factors and non-work factors). Our findings clearly show that Chinese expatriates are facing difficulties regarding the work environment in Pakistan (see Table 2). The main work-related challenges for Chinese expats are "different time perceptions" and "work style differences." Past studies have also confirmed that Chinese expatriates face different challenges related to their work in Pakistan. In addition, the main concern shown by the respondents is the delaying of tasks and working habits of Pakistani people, resulting in obstacles in their adjustment [46].

The study also highlights challenges regarding Chinese expatriate's non-works factors that affect their adjustment in Pakistan (see Table 3). The major challenges are the "language barrier" and "cultural differences" in Pakistan [46].

The second aim of this research to enhance the expatriates' adjustment in the host country. According to the literature, CCT is an effective method for aiding expatriates' cross-cultural adjustment. Furthermore, our study suggests that CCT is intended to help expatriates feel more useful in international assignments [57]. Our study highlights the two methods that are used by expatriates to acquire information and knowledge of the host country (i.e., formal learning and informal learning). According to Tissot [90], formal learning programs are usually offered by companies or training institutions; hence, we conclude that the pre-departure training method is a formal way of learning, which is provided by the company prior to the departure of expatriates. The results show that Chinese expatriates with pre-departure training have easily adjusted in Pakistan (see Table 3). Past studies have also confirmed that this initial cross-cultural training provides basic information on the host country, which is necessary for the immediate training of expatriates upon arrival at their intended location. For instance, these training techniques may help expatriates to learn about cultural paradigms and norms, the country's business protocols, the dressing norms of that country, essential customs, and basic knowledge of the language [91].

On the other hand, the study highlights the informal learning techniques of expatriates (shown as Appendix A). In this study, these informal learning techniques are usually arranged by expatriates themselves. Results regarding informal learning clearly show that Chinese expatriates use informal ways of learning before coming to Pakistan. In the digital modern age, research conducted by Bear [68] indicates that today's expatriates mostly get essential knowledge of their host country by means of informal learning using internet technologies (i.e., Google, Facebook, Whatsapp, Webchat, e-mail, and blogs). 


\section{Limitation and Directions for Future Research}

There are several limitations to this research. First, our research is based on qualitative methods and we collected data via semi-structured interviews of medium level management Chinese expats performing their duties in distinct Chinese firms in Pakistan in 2018. We focused on English speaking Chinese employees, which helped to recognize that their challenges, along with their adjustment, varied with their experiences. In the future, scholars could conduct research not only on English speaking Chinese expatriates but also non-English speaking Chinese; for instance, comparing their adjustment process and recognizing their difficulties as compared to English speaking Chinese expatriates. Our attention on expatriates at the medium level helped to develop comprehensive knowledge of their adaptation, but the adaptation of expatriates employed at different levels and roles differs. Therefore, future studies will conduct research which include different levels, for instance, identifying their adaptation process and recognizing that their adaptation challenges varies according to their different management levels.

Second, the numbers of Chinese expatriates are limited, and findings have demonstrated a positive relation regarding CCT and expatriates' adjustment. Thus, future research may investigate the finding of this research by using quantitative methodologies.

Finally, the study is only limited to Chinese expatriates and we collected data from Chinese expatriates only. Therefore, future research may focus on gathering data from Pakistani workers on the assistance and facilitation provided to Chinese expatriates in Pakistan. Furthermore, this study was limited to collecting data from only two industries, i.e., telecommunication and manufacturing. Hence, future research can be conducted on other industries as well to broaden our understanding about expatriates.

\section{Conclusions}

Based on a qualitative approach, it was found that difficulties are often encountered by Chinese expatriates in cross-cultural transition periods. Expatriates' adjustment challenges were linked to their vulnerability in the diverse social, cultural, language, and working climate of the host country. In addition, Baker and Ivancevich [92] suggested that by providing rigorous training to expatriates before leaving the home country, they will be more prepared for the upcoming "culture shock". While Chinese firms extend their activities worldwide to different countries, covering Asian and African regions, we suggest that organizations develop a series of CCT programs based on various types of expatriates. We assume that CCT will contribute positively to both expatriation and the entire firm. CCT will make expats feel more comfortable and adjust more easily, and provide a fundamental understanding of the host country's culture. Further, language skills are important for expatriates' to grasp the host country's culture [93]. Therefore, organizations may offer language training to expatriates for their successful international assignment, irrespective of where the training takes place [94].

Author Contributions: M.N. contributed to the conceptualization, formal analysis, investigation, methodology, writing of the original draft, and writing review and editing. All the other authors contributed to the formal analysis, investigation, methodology, and writing review and editing. All authors have read and agreed to the published version of the manuscript.

Funding: This research received no external funding

Conflicts of Interest: The authors declare no conflict of interest.

\section{Appendix A}

Q1. What is your perception about Pakistan?

Q2. How did you perceive Pakistan before visiting and now how do you see it?

Q3. How long you have been here?

Q4. What kind of problem did you face here in Pakistan? 
Q5. What are the key barriers while adjusting to work environment in Pakistan?

Q6. Did you take any cross cultural training before visiting Pakistan?

\section{References}

1. Axelsson, R.; Angelstam, P.; Degerman, E.; Teitelbaum, S.; Andersson, K.; Elbakidze, M.; Drotz, M.K. Social and cultural sustainability: Criteria, indicators, verifier variables for measurement and maps for visualization to support planning. Ambio 2013, 42, 215-228. [CrossRef] [PubMed]

2. Soini, K.; Birkeland, I. Exploring the scientific discourse on cultural sustainability. Geoforum 2014, 51, $213-223$. [CrossRef]

3. Jackson, T.; Horwitz, F.M. Expatriation in Chinese MNEs in Africa: An agenda for research. Int. J. Hum. Resour. Manag. 2017, 29, 1856-1878. [CrossRef]

4. Buckley, P.J.; Clegg, L.J.; Voss, H.; Cross, A.R.; Liu, X.; Zheng, P. A retrospective and agenda for future research on Chinese outward foreign direct investment. J. Int. Bus. Stud. 2018, 49, 4-23. [CrossRef]

5. Zhang, M.M.; Fan, D. Expatriate skills training strategies of Chinese multinationals operating in Australia. Asia Pac. J. Hum. Resour. 2014, 52, 60-76. [CrossRef]

6. Cooke, F.L.; Yao, X.; Jiang, Y.; Li, A.S. Space, agency and overseas employment for Chinese university graduates in a transient global labour market. Int. J. Hum. Resour. Manag. 2017, 28, 2622-2655. [CrossRef]

7. Huang, Y. Understanding China's Belt \& Road initiative: Motivation, framework, and assessment. China Econ. Rev. 2016, 40, 314-321. [CrossRef]

8. Ahmad, T. Silk Road to (economic) Heaven. Herard Retrieved, 18 June 2016, pp. 3-8. Available online: https://herald.dawn.com/news/1153432 (accessed on 25 December 2019).

9. Abdul Malek, M.; Budhwar, P.; Reiche, B.S. Sources of Support and Expatriation: A multiple stakeholder perspective of expatriate adjustment and performance in Malaysia. Int. J. Hum. Resour. Manag. 2015, 26, 258-276. [CrossRef]

10. Bruning, N.S.; Sonpar, K.; Wang, X. Host-country national networks and expatriate effectiveness: A mixed-methods study. J. Int. Bus. Stud. 2012, 43, 444-450. [CrossRef]

11. Kawai, N.; Mohr, A. The Contingent Effects of Role Ambiguity and Role Novelty on Expatriates' Work-related Outcomes. Br. J. Manag. 2015, 26, 163-181. [CrossRef]

12. Selmer, J.; Lauring, J. Host country language ability and expatriate adjustment: The moderating effect of language difficulty. Int. J. Hum. Resour. Manag. 2015, 26, 401-420. [CrossRef]

13. Zhang, Y.; Oczkowski, E. Exploring the potential effects of expatriate adjustment direction. Cross Cult. Strateg. Manag. 2016, 23, 158-183. [CrossRef]

14. Selmer, J. Language ability and adjustment: Western expatriates in China. Thunderbird Int. Bus. Rev. 2006, 48, 347-368. [CrossRef]

15. Black, J.S.; Mendenhall, M.E.; Oddou, G. Toward a comprehensive model of international adjustment: An integration of multiple theoretical perspectives. Acad. Manag. Rev. 1991, 16, 291-317. [CrossRef]

16. Black, J.S.; Stephens, G.K. The influence of the spouse on American expatriate adjustment and intent to stay in Pacific Rim overseas assignments. J. Manag. 1989, 15, 529-544. [CrossRef]

17. Goby, V.P.; Ahmed, Z.U.; Annavarjula, M.; Lbrahim, D.N.; Osman-Gani, A. Determinants of expatriate success: An empirical study of Singaporean expatriates in The Peoples Republic of China. J. Transnatl. Manag. Dev. 2002, 7, 73-88. [CrossRef]

18. Zhou, X.; Qin, J. A Study on Cross-Cultural Adjustment of Japanese and American Expatriates in China. Int. J. Bus. Manag. 2009, 4. [CrossRef]

19. Neuliep James, W. Intercultural Communication: A Contextual Approach; Houghton Mifflin Company: Boston, MA, USA; New York, NY, USA, 2003. Available online: https://trove.nla.gov.au/version/45808257 (accessed on 10 December 2019).

20. Wild, J.J.; Wild, K.L.; Han, J.C.Y. International Business: An Integrated Approach; Prentice Hall: Upper Saddle River, NJ, USA, 2000. Available online: https://trove.nla.gov.au/version/41180087 (accessed on 18 December 2019).

21. Adler, N.J.; Gundersen, A. International Dimensions of Organizational Behavior, 5th ed.; Cengage Learning: Boston, MA, USA, 2007; p. 416.

22. Grundey, D. International and Cross-Cultural Business Environment: Modelling The Training Process of Expatriates. Transform. Bus. Econ. 2008, 7, 114-129. 
23. Eschbach, D.M.; Parker, G.E.; Stoeberl, P.A. American repatriate employees' retrospective assessments of the effects of cross-cultural training on their adaptation to international assignments. Int. J. Hum. Resour. Manag. 2001, 12, 270-287. [CrossRef]

24. Searle, W.; Ward, C. The prediction of psychological and sociocultural adjustment during cross-cultural transitions. Int. J. Intercult. Relat. 1990, 14, 449-464. [CrossRef]

25. Ward, C.; Kennedy, A. Locus of control, mood disturbance, and social difficulty during cross-cultural transitions. Int. J. Intercult. Relat. 1992, 16, 175-194. [CrossRef]

26. Ward, C.; Kennedy, A. Crossing Cultures: The Relationship Between Psychological and Socio-Cultural Dimensions of Cross-Cultural Adjustment; Sage Publications: Southend Oaks, CA, USA, 1996.

27. Grove, C.L.; Torbiörn, I. A new conceptualization of intercultural adjustment and the goals of training. Int. J. Intercult. Relat. 1985, 9, 205-233. [CrossRef]

28. Oberg, K. Cultural shock: Adjustment to new cultural environments. Pract. Anthropol. 1960, 4, $177-182$. [CrossRef]

29. Black, J.S. The relationship of personal characteristics with the adjustment of Japanese expatriate managers. MIR Manag. Int. Rev. 1990, 30, 119-134. Available online: https://www.jstor.org/stable/pdf/40228014.pdf? seq=1 (accessed on 12 November 2019).

30. Parker, B.; McEvoy, G.M. Initial examination of a model of intercultural adjustment. Int. J. Intercult. Relat. 1993, 17, 355-379. [CrossRef]

31. Caligiuri, P.M. The big five personality characteristics as predictors of expatriate's desire to terminate the assignment and supervisor-rated performance. Pers. Psychol. 2000, 53, 67-88. [CrossRef]

32. Black, J.S. Work role transitions: A study of American expatriate managers in Japan. J. Int. Bus. Stud. 1988, 19, 277-294. [CrossRef]

33. Lazarova, M.; McNulty, Y.; Semeniuk, M. Expatriate family narratives on international mobility: Key characteristics of the successful moveable family. In Work and Family Interface in the International Career Context; Springer: Berlin/Heidelberg, Germany, 2015; pp. 29-51. [CrossRef]

34. Rosenbusch, K.; Cseh, M. The cross-cultural adjustment process of expatriate families in a multinational organization: A family system theory perspective. Hum. Resour. Dev. Int. 2012, 15, 61-77. [CrossRef]

35. Dowling, P.; Welch, D. IHRM: Managing People in a Multinational Context; Thomson Lear: Toronto, ON, Canada, 2005.

36. Briscoe, D.R.; Schuler, R.S. International Human Resource Management: Policy and Practice for the Global Enterprise, illustrated.; Routledge: London, UK, 2004; Volume 5.

37. Caligiuri, P.; Bonache, J. Evolving and Enduring Challenges in Global Mobility. J. World Bus. 2016, 51, $127-141$. [CrossRef]

38. Toh, S.M.; DeNisi, A.S. Host country nationals as socializing agents: A social identity approach. J. Organ. Behav. Int. J. Ind. Occup. Organ. Psychol. Behav. 2007, 28, 281-301. [CrossRef]

39. Varma, A.; Pichler, S.; Budhwar, P.; Kupferer, S. Expatriate-local interactions: An investigation in China. J. Manag. Psychol. 2012, 27, 753-768. [CrossRef]

40. Zhang, L.E.; Guttormsen, D.S. "Multiculturality" as a key methodological challenge during in-depth interviewing in international business research. Cross Cult. Strateg. Manag. 2016, 23, 232-256. [CrossRef]

41. Bhaskar-Shrinivas, P.; Harrison, D.A.; Shaffer, M.A.; Luk, D.M. Input-Based and Time-Based Models of International Adjustment: Meta-analytic Evidence and Theoretical Extensions. Acad. Manag. J. 2005, 48, 257-281. [CrossRef]

42. Takeuchi, R. A critical review of expatriate adjustment research through a multiple stakeholder view: Progress, emerging trends, and prospects. J. Manag. 2010, 36, 1040-1064. [CrossRef]

43. Lee, L.-Y.; Veasna, S.; Wu, W.-Y. The effects of social support and transformational leadership on expatriate adjustment and performance: The moderating roles of socialization experience and cultural intelligence. Career Dev. Int. 2013, 18, 377-415. [CrossRef]

44. Tenzer, H.; Pudelko, M.; Harzing, A.-W. The impact of language barriers on trust formation in multinational teams. J. Int. Bus. Stud. 2014, 45, 508-535. [CrossRef]

45. Parhizgar, K.D. Multicultural Behavior and Global Business Environments; Routledge: Abingdon upon Thames, UK, 2013.

46. Nadeem, S.; Mumtaz, S. Expatriates adjustment through transformation of social identity of Chinese expatriates working in Pakistan. Cross Cult. Strateg. Manag. 2018, 25, 642-669. [CrossRef] 
47. Shaffer, M.A.; Harrison, D.A.; Gilley, K.M. Dimensions, determinants, and differences in the expatriate adjustment process. J. Int. Bus. Stud. 1999, 30, 557-581. [CrossRef]

48. Selmer, J. Cross-cultural training and expatriate adjustment in China: Western joint venture managers. Pers. Rev. 2005, 34, 68-84. [CrossRef]

49. Yavas, U.; Bodur, M. Correlates of adjustment: A study of expatriate managers in an emerging country. Manag. Decis. 1999, 37, 267-279. [CrossRef]

50. Harzing, A.-W.; Pinnington, A. International Human Resource Management; Sage: Newcastle upon Tyne, UK, 2010.

51. Mendenhall, M.E.; Oddou, G.R. Succession planning for the 21st century: How well are we grooming our future business leaders? Bus. Horiz. 1991, 34, 26-35. [CrossRef]

52. Brislin, R.W.; Pedersen, P.B. Cross-Cultural Orientation Programs; Halsted Press: Sydney, Austrilia, 1976.

53. Waxin, M.-F.; Panaccio, A. Cross-cultural training to facilitate expatriate adjustment: It works! Pers. Rev. 2005, 34, 51-67. [CrossRef]

54. Forster, N. Managing Staff on International Assignments. A strategic Guide; Pearson Merrill Prentice Hall: Great Britain, UK, 2000.

55. Black, J.S.; Mendenhall, M. Cross-cultural training effectiveness: A review and a theoretical framework for future research. Acad. Manag. Rev. 1990, 15, 113-136. [CrossRef]

56. Porter, G.; Tansky, J.W. Expatriate success may depend on a "learning orientation": Considerations for selection and training. Hum. Resour. Manag. Publ. Coop. Sch. Bus. Adm. Univ. Mich. Alliance Soc. Hum. Resour. Manag. 1999, 38, 47-60.

57. Caligiuri, P.; Lazarova, M.; Tarique, L. Training, learning and development in multinational organizations. Int. Hum. Resour. Manag. A Crit. Text 2005, 71-90. [CrossRef]

58. Deal, T.E.; Kennedy, A.A. Corporate Cultures: The Rites and Rituals of Corporate Life; Addison Wesley Reading: Boston, MA, USA, 1982.

59. Mondy, R.W.; Noe, R.M. Administración de Recursos Humanos; Pearson Educación: Mexico City, Mexico, 2005.

60. Brislin, R.W. Cross-Cultural Encounters, Face-to-Face Interaction: Face-to-Face Interaction; Pergamon Press: Oxford, UK, 1981. Available online: https://trove.nla.gov.au/version/49090846 (accessed on 20 November 2019).

61. Scullion, H.; Collings, D.G. International Recruitment and Selection; High, S., David, G.C., Eds.; Global Staffing London \& New York: London, UK; New York, NY, USA; Routledge: Abingdon upon Thames, UK, 2006. Available online: https://trove.nla.gov.au/work/33462633 (accessed on 28 November 2019).

62. Suutari, V.; Burch, D. The role of on-site training and support in expatriation: Existing and necessary host-company practices. Career Dev. Int. 2001, 6, 298-311. [CrossRef]

63. Sims, R.H.; Schraeder, M. An Examination of Salient Factors Affecting Expatriate Culture Shock. J. Bus. Manag. 2004, 10, 73-88.

64. Mark, E.; Mendenhall, A.; Wiley, C. Strangers in a Strange Land. Am. Behav. Sci. 1994, 37, 605-620. [CrossRef]

65. Tissot, P.; Professionnelle, C. Terminology of Vocational Training Policy: A Multilingual Glossary for an Enlarged Europe; Office for Official Publications of the European Communities Luxembourg: Brussels, Belgium, 2004.

66. Brewster, C.; Pickard, J. Evaluating Expatriate Training. Int. Stud. Manag. Organ. 1994, 24, 18-35. [CrossRef]

67. Ghafoor, S.; Khan, U.F. Facilitating expatriates cross cultural adjustment (A case study of expatriates from Pakistani organization on foreign assignments). J. Asian Sci. Res. 2011, 1, 176-193. Available online: https://econpapers.repec.org/article/asijoasrj/ (accessed on 8 November 2019).

68. Bear, D.; American Society for Training and Development; Institute for Corporate Productivity. Tapping the Potential of Informal Learning; American Society for Training and Development: Alexandria, VA, USA, 2008.

69. Sambrook, S. Factors influencing the context and process of work-related learning: Synthesizing findings from two research projects. Hum. Resour. Dev. Int. 2005, 8, 101-119. [CrossRef]

70. Ellinger, A.D. Contextual factors influencing informal learning in a workplace setting: The case of "reinventing itself company". Hum. Resour. Dev. Q. 2005, 16, 389-415. [CrossRef]

71. Marsick, V.J.; Volpe, M. The nature and need for informal learning. Adv. Dev. Hum. Resour. 1999, 1, 1-9. [CrossRef]

72. Caligiuri, P.; Phillips, J.; Lazarova, M.; Tarique, I.; Burgi, P. The theory of met expectations applied to expatriate adjustment: The role of cross-cultural training. Int. J. Hum. Resour. Manag. 2001, 12, 357-372. [CrossRef] 
73. Wang, D.; Freeman, S.; Zhu, C.J. Personality traits and cross-cultural competence of Chinese expatriate managers: A socio-analytic and institutional perspective. Int. J. Hum. Resour. Manag. 2013, 24, 3812-3830. [CrossRef]

74. Birkinshaw, J.; Brannen, M.Y.; Tung, R.L. From a Distance and Generalizable to up Close and Grounded: Reclaiming a Place for Qualitative Methods in International Business Research; Springer: Berlin/Heidelberg, Germany, 2011.

75. Yin, R.K. Qualitative Research from Start to Finish; Guilford Publications: New York, NY, USA, 2015.

76. Silverman, D. Interpreting qualitative data: A guide to the principles of qualitative research. In Interpreting Qualitative Data; Sage: London, UK, 2011; pp. 57-86. Available online: http://blogs.ubc.ca/outofplace/files/ 2013/09/Silverman-2011-Ch-3.pdf (accessed on 10 December 2019).

77. Murray, G. Narrative inquiry. In Qualitative research in applied linguistics; Springer: Berlin/Heidelberg, Germany, 2009; pp. 45-65. [CrossRef]

78. Arduino, A. China's Belt and Road Initiative Security Needs: The Evolution of Chinese Private Security Companies; Nanyang Technological University: Singapore, 2017; pp. 306-317. Available online: http://hdl.handle.net/ 10220/43712 (accessed on 11 September 2019).

79. Sial, S. The China-Pakistan Economic Corridor: An assessment of potential threats and constraints. Confl. Peace Stud. 2014, 6, 24. Available online: http://pakistanhouse.net/wp-content/uploads/2016/11/cpec.pdf (accessed on 11 September 2019).

80. Glassock, G.; Fee, A. The decision-making processes of self-initiated expatriates: A consumer behaviour approach. J. Glob. Mobil. 2015, 3, 4-24. [CrossRef]

81. Green, S.D.; Kao, C.C.; Larsen, G.D. Contextualist research: Iterating between methods while following an empirically grounded approach. J. Constr. Manag. Eng. 2010, 136, 117-126. [CrossRef]

82. Inkson, K.; Myers, B.A. “The big OE”: Self-directed travel and career development. Career Dev. Int. 2003, 8, 170-181. [CrossRef]

83. Myers, B.; Pringle, J.K. Self-initiated foreign experience as accelerated development: Influences of gender. J. World Bus. 2005, 40, 421-431. [CrossRef]

84. Flick, U. The Sage Qualitative Research Kit: Collection; SAGE Publications Limited: Newcastle upon Tyne, UK, 2009.

85. Rademaker, L.L. Qualitative research from start to finish: A book review. Qual. Rep. 2011, 16, $1452-1455$. Available online: https://nsuworks.nova.edu/tqr/vol16/iss5/15 (accessed on 8 November 2019).

86. Sutton, J.; Austin, Z. Qualitative research: Data collection, analysis, and management. Can. J. Hosp. Pharm. 2015, 68, 226. [CrossRef]

87. Braun, V.; Clarke, V. Using thematic analysis in psychology. Qual. Res. Psychol. 2006, 3, 77-101. [CrossRef]

88. Braun, V.; Clarke, V. Thematic analysis. APA Handbook of Research Methods in Psychology, Vol 2: Research Designs: Quantitative, Qualitative, Neuropsychological, and Biological. Am. Psychol. Assoc. 2012. [CrossRef]

89. King, N. Using templates in the thematic analysis of text. In Essential Guide to Qualitative Methods in Organizational Research; SAGE Publishing: Thousand Oak, CA, USA, 2004; Volume 2, pp. 256-270. [CrossRef]

90. Tissot, P. Terminology of Education and Training Policy: A Multilingual Glossary; CedefopEd: Luxembourg, 2008.

91. Avril, A.B.; Magnini, V.P. A Holistic Approach to Expatriate Success. Int. J. Contemp. Hosp. Manag. 2007, 19, 53-64. [CrossRef]

92. Baker, J.C.; Ivancevich, J.M. The Assignment of American Executives Abroad: Systematic, haphazard or chaotic? Calif. Manag. Rev. 1971, 13, 39-44. [CrossRef]

93. Ferraro, G.P. The Cultural Dimension of International Business, 4th ed.; Prentice Hall: Upper Saddle River, NJ, USA, 2002.

94. Dickmann, M.; Doherty, N.; Mills, T.; Brewster, C. Why do they go? Individual and corporate perspectives on the factors influencing the decision to accept an international assignment. Int. J. Hum. Resour. Manag. 2008, 19, 731-751. [CrossRef]

(C) 2020 by the authors. Licensee MDPI, Basel, Switzerland. This article is an open access article distributed under the terms and conditions of the Creative Commons Attribution (CC BY) license (http://creativecommons.org/licenses/by/4.0/). 